\title{
Middle Ear
}

National Cancer Institute

\section{Source}

National Cancer Institute. Middle Ear. NCI Thesaurus. Code C12274.

The part of the ear including the eardrum and ossicles. The middle ear leads to the inner ear. 